\title{
Bat flies (Diptera, Streblidae and Nycteribiidae) in a Cerrado area of Goiás State, Brazil
}

\author{
Gustavo Graciolli ${ }^{1}$, Marlon Zortéa ${ }^{2} \&$ Luiz Felipe Alves da Cunha Carvalho ${ }^{1}$
}

\begin{abstract}
${ }^{1}$ Programa de Pós-Graduação em Ecologia e Conservação, Departamento de Biologia, Universidade Federal de Mato Grosso do Sul, $79070-900$ Campo Grande-MS, Brazil ggraciolli@yahoo.com.br

2Programa de Pós-Graduação em Ecologia e Evolução, Universidade Federal de Goiás, Campus Jataí, Br 364, Km 192, 75801-615 Jataí-GO, Brazil. mzortea@ uol.com.br
\end{abstract}

\begin{abstract}
Bat flies (Diptera, Streblidae and Nycteribiidae) in a Cerrado area of state of Goiás, Brazil. A survey of bat flies was carried out in the Brazilian savanna (Cerrado) in the Goiás state, Brazil. We collected 227 specimens of seventeen species belonging to nine genera of Streblidae and seven specimens of four species of Basilia Miranda-Ribeiro, 1903 (Nycteribiidae). Except for Paratrichobius longicrus (Miranda-Ribeiro, 1907) (Streblidae), all species are new recorded in Goiás.
\end{abstract}

KEYWORDS. Biodiversity; Hippoboscoidea; host; parasite.

RESUMO. Dípteros ectoparasitos de morcegos em uma área de cerrado no estado de Goiás, Brasil. Realizamos um levantamento dos ectoparasitas em uma taxocenose de morcegos em uma área de Cerrado no Brasil central, em Goiás. Nós coletamos 227 espécimes de 17 táxons de nove gêneros de Streblidae e sete indivíduos de quatro espécies de Basilia (Nycteribiidae). Excetuandose Paratrichobius longicrus (Miranda-Ribeiro, 1907) (Streblidae), todas demais espécies são novos registros para o estado de Goiás.

PALAVRAS-CHAVE. Biodiversidade; Hippoboscoidea; hospedeiro; parasito.

Bat flies (Diptera, Streblidae and Nycteribiidae) are one of the most common exclusively bat ectoparasites. In Brazil, 68 species from 20 genera of streblid bat flies and 25 species from two genera of nicteribiid bat flies have been recorded (Graciolli et al. 2007, 2008). Presently, 24 species from eight genera of streblid, and four species of Basilia (MirandoRibeiro, 1907) are found in the Cerrado of the Distrito Federal, and in the states of Mato Grosso do Sul, Minas Gerais, and Tocantins (Graciolli et al. 2008). In Goiás state, Pessôa and Guimarães (1936) recorded the occurrence of Paratrichobius longicrus (Miranda-Ribeiro, 1907) (Streblidae) on Artibeus planirostris (Spix, 1823). Here, we present data of a bat flies inventory conducted in a Cerrado area of the state of Goiás, Central Brazil.

The field work was carried out in a protected area known as a private natural heritage reserve, "Reserva Particular do Patrimônio Natural Pousada das Araras", municipality of Serranópolis, Southwestern Goiás, Brazil $\left(18^{\circ} 25^{\prime} \mathrm{S}\right.$ and $52^{\circ} 00^{\prime} \mathrm{W}$ ), with altitudes varying from 500 to $700 \mathrm{~m}$. The area of the reserve has 175 ha, but the preserved Cerrado fragment spreads throughout the region surrounding the reserve. The climate is classified as typical tropical savanna Aw, according to the classification of Köppen (1948). The climate of the Cerrado is usually divided in two well defined seasons: the dry season, from May to September, and the wet season, from October to April, with an average annual precipitation of $600-2,000 \mathrm{~mm}$ (Lima \& Silva 2005). The annual precipitation in Serranópolis is around 1,400 mm, with the dry and cold season from May to August and the rainy season being more intense from December to March (FUNATURA 1999). More information about study area is found in Zortéa \& Alho (2008).

Bats were captured monthly from August 2000 through July 2001 (except February), in the darkest nights. We carried out 4-6 capture samples per month, depending on weather conditions. In total, we performed 60 days of capture, resulting in about $240 \mathrm{~h}$ of sampling effort. The bats were collected in mist nets of 6,9 , and $12 \mathrm{~m}$ in length by $2.8 \mathrm{~m}$ in height, set in trails, clearings, edge of rivers and creeks, and in the interior of vegetation. Each month, three different places were sampled in the reserve. The mist nets were opened at sunset, generally half an hour before dark, and stayed open for $4 \mathrm{~h}$. The bats were previously identified in the field but some specimens were collected for taxonomic identification in the laboratory. The collected bats were deposited at Chiroptera Collection of "Universidade Federal de Goiás, Campus Jataí" (CCUFG).

During each bat inspection, the presence or absence of ectoparasites was recorded. When present, the parasites were individually placed in labeled eppendorf vials containing $70 \%$ ethanol. The bat flies were removed of body's host with fine twizers. The bat flies are deposited in the Zoological Collection of "Universidade Federal do Mato Grosso do Sul".

A total of 227 specimens of 17 species in nine genera of 
Streblidae and seven specimens of four species of Basilia Miranda-Ribeiro, 1903 (Nycteribiidae) were collected. Except for Paratrichobius longicrus, all species are new records for Goiás state.

In the examined material is presented the number of specimens of each sex, host and data collection. Remarks on the species were made when deemed appropriate.

\section{Nycteribiidae}

\section{Basilia anceps Guimarães \& D’Andretta, 1956}

Material examined ( 2 males and 1 female). 1 male and 1 female, ex. Myotis sp. (released), 27/III/2001. 1 male, ex. Myotis sp. (released), IV/2001.

Remarks. In Brazil, B. anceps had been recorded in Distrito Federal on Myotis nigricans (Schinz, 1821) and Myotis riparius Handley, 1960 (Graciolli et al. 2008).

\section{Basilia hughscotii Guimarães, 1946}

Examined material. 1 female, ex. Myotis sp. (released), IV/2001.

Remarks. Basilia hughscotti had already been recorded in Cerrado in Minas Gerais and Distrito Federal (Graciolli et al, 2008).

\section{Basilia tiptoni Guimarães, 1966}

Examined material. 1 male, ex. Mimon crenulatum (E. Geoffroy, 1803) (released), XI/2000.

\section{Basilia sp.}

Examined material. 1male and 1 female, ex. Myotis sp. (released), 27/ III/2001

Remarks. Species very similar B. quadrosae Graciolli \& Moura, 2004 and B. ortizi Machado-Allison, 1964. Probably these specimens belong to an undescribed species.

\section{Streblidae \\ Anastrebla modestini Wenzel, 1966}

Examined material (3 males and 1 female). 1 male, ex. Anoura geoffroyi Gray, 1818 (released), 30/X/2000. 1 male, ex. A. geoffroyi (released), 25/ XII/2000. 1 female, ex. Anoura caudifer (E. Geoffroy, 1818) (released), I/2001. 1 male, ex. A. geoffroyi (released), 23/IV/2001.

Aspidoptera phyllostomatis (Perty, 1899)

Examined material (17 males and 10 females). 1 male and 1 female, ex. Artibeus planirostris (released), 29/IX/2000. 5 males and 3 females, ex. A. planirostris (released), 25/XII/2000. 4 males and 2 females, ex. A. planirostris (CCUFG 428), 27///2001. 5 males and 3 females, ex. A. planirostris (released), 23/III/2001. 2 males, ex. A. planirostris (released), 23/IV/2001.

Remarks. Aspidoptera phyllostomatis is a specific parasite of species of the genus Artibeus Leach, 1821 (Wenzel et al. 1966; Wenzel 1976).

\section{Exastinion clovisi (Pessôa \& Guimarães, 1937)}

Examined material ( 7 males and 7 females). 1 male and 1 female, ex. Anoura geoffroyi (released), 05/IX/2000. 1 female, ex. A. geoffroyi (released), 28/IX/2000. 4 males and 3 females, ex. A. geoffroyi (released), 30/ $\mathrm{X} / 2000.1$ male, ex. A. geoffroyi (released), 25/XII/2000. 1 male and 1 female, ex. A. geoffroyi (released), 27/I/2001. 1 female, ex. Anoura caudifer (released), I/2001.

\section{Mastoptera minuta complex (Wenzel, 1966)}

Examined material. 2 females, ex. Lophostoma brasiliense Peters, 1866 (released), VII/2000.

\section{Megistopoda aranea (Coquillett, 1899)}

Examined material (44 males and 26 females). 1 male, ex. Artibeus planirostris, 29/IX/2000 (released). 1 female, ex. A. planirostris, IX/2000 (released). 4 males and 4 females, ex. A. planirostris, XI/2000 (released). 11 males and 2 females, ex. A. planirostris, 25/XII/2000 (released). 15 males and 11 females, ex. A. planirostris, 27/I/2001 (CCUFG 428). 13 males and 6 females, ex. A. planirostris, 23/III/2001 (released). 2 females, ex. $A$. planirostris, 23/IV/2001 (released).

\section{Megistopoda proxima (Séguy, 1926)}

Examined material (14 males and 9 females). 3 males and 1 female, ex. Sturnira lilium (E. Geoffroy, 1810), 05/IX/2000 (CCUFG 63). 1 female, ex. S. lilium (released), 30/X/2000. 1 male and 1 female, ex. S. lilium (released), 25/XII/2000. 1 male, ex. S. lilum (released), 23/III/2001. 9 males and 6 females, ex. S. lilium (released), 23/IV/2001.

\section{Paratrichobius longicrus (Miranda-Ribeiro, 1907)}

Examined material (4 males and 2 females). 2 males, ex. Platyrrhinus lineatus (E. Geoffroy, 1810) (released), 05/IX/2000. 1 female, ex. $P$. lineatus, XI/2000. 1 male and 1 female, ex. P. lineatus (released), 23/ IV/2001. 1 male, ex. P. lineatus (released), V/2001.

Remarks. Paratrichobius longicrus is a complex of species that parasites bats of the genera Artibeus and Platyrrhinus Saussure, 1860 (Wenzel et al. 1966). Pessôa \& Guimarães (1936) recorded $P$. longicrus on Artibeus planirostris in Goiás. In others cerrado areas, $P$. longicrus were only recorded on $P$. lineatus in Mato Grosso do Sul (Graciolli et al. 2006) and Minas Gerais (Komeno \& Linhares 1999). Probably, the specimens that parasitize $P$. lineatus belong to a different species that the specimens found on $A$. planirostris or A. lituratus (Olfers, 1818).

\section{Strebla curvata Wenzel, 1976}

Examined material. 1 male, ex. Glossophaga soricina (Pallas, 1766) (released), V/2001.

\section{Strebla wiedemanni Kolenati, 1856}

Examined material. 1 male, ex. Desmodus rotundus (E. Geoffroy, 1810) (CCUFG 53), 04/IX/2000. 1 male, ex. D. rotundus, 30/X/2000 (released). 1 male, ex. D. rotundus (CCUFG 247), XI/2000.

\section{Trichobioides perspicillatus (Pessôa \& Galvão, 1937)}


Table I. Number of species of Streblidae and Nycteribiidae found by Brazilian states (source: Dias et al. 2009; Graciolli et al. 2007, 2008; Rios et al. 2008)

\begin{tabular}{lccc}
\hline \multirow{2}{*}{ STATE } & \multicolumn{2}{c}{ NUMBER OF SPECIES } & \multirow{2}{*}{ TOTAL } \\
\cline { 2 - 3 } & Streblidae & Nycteribiidae & \\
\hline Distrito Federal & 37 & 03 & 40 \\
Paraná & 31 & 08 & 39 \\
São Paulo & 25 & 14 & 39 \\
Pará & 28 & 03 & 31 \\
Maranhão & 22 & 01 & 23 \\
Santa Catarina & 15 & 08 & 23 \\
Minas Gerais & 18 & 04 & 22 \\
Goiás & 17 & 04 & 21 \\
Rio Grande do Sul & 13 & 04 & 17 \\
Roraima & 14 & 02 & 16 \\
Rondônia & 13 & 00 & 13 \\
Amazonas & 08 & 03 & 11 \\
Rio de Janeiro & 08 & 02 & 10 \\
Mato Grosso & 05 & 03 & 08 \\
Mato Grosso do Sul & 06 & 01 & 07 \\
Bahia & 04 & 00 & 04 \\
Pernambuco & 03 & 01 & 04 \\
Ceará & 02 & 01 & 03 \\
Espírito Santo & 02 & 00 & 02 \\
Tocantins & 01 & 00 & 01 \\
\hline
\end{tabular}

1843, 30/X/2000. 1 male and 1 female, ex. P. discolor (released), 23/ III/2001.

\section{Trichobius affinis Wenzel, 1976}

Examined material. 1 female, ex. Lophostoma brasilense, VI/2001. 1 male, ex. L. brasiliense, VII/2001.

\section{Trichobius costalimai Guimarães, 1938}

Examined material ( 8 males and 2 females). 3 males and 1 female, ex. Phyllostomus discolor (released), 30/X/2000. 5 males and 1 female, ex. P. discolor (released), 23/III/2001.

\section{Trichobius dugesii Townsend, 1891}

Examined material (6 males and 2 females). 2 males, ex. Glossophaga soricina, 05/IX/2000 (released). 1 female, ex. G. soricina (released), 28/ IX/2000. 1 male, ex. G. soricina (released), 27/I/2001. 1 female, ex. G. soricina (released), 23/III/2001. 3 males, ex. G. soricina (released), $\mathrm{V} / 2001$.

\section{Trichobius joblingi Wenzel, 1966}

Examined material (11 males and 4 females). 2 males and 2 females, ex.Carollia perspicillata (L., 1758) (released), 30/X/2000. 1 male, ex. C. perspicillata (released), V/2001. 1 male and 1 female, ex. C. perspicillata (released), IX/2000. 7 males and 1 females, ex. $C$. perspicillata (released), VII/2001.

\section{Trichobius parasiticus Gervais, 1844}

Examined material. 1 male and 1 female, ex. Desmodus rotundus (CCUFG 53), 04/IX/2000. 1 female, ex. D. rotundus (CCUFG 83), 28/IX/2000.

\section{Trichobius tiptoni Wenzel, 1976}

Examined material ( 3 males and 3 females). 1 male, ex. Anoura caudifer (released), 01/X/2000. 1 male and 1 female, ex. Anoura geoffroyi (released), 30/X/2000. 1 female, ex. A. caudifer (released), 23/III/2001.

1 male and 1 female, ex. A. caudifer (released), V/2001.

\section{Trichobius uniformis Curran, 1935}

Examined material. 1 female, ex. Glossophaga soricina (released), V/2001. 1 male, ex. G. soricina (released), VII/2001.

The following captured species of host did not harbour bat flies: Mesophylla macconnelli Thomas, 1901, Glyphonycteris aff. behnii (Peters, 1865), Mimon bennettii (Gray, 1838), Molossops temminckii (Burmeister, 1854) (Molossidae), Eptesicus diminutus (Osgood, 1915), and Lasiurus ega (Gervais, 1856) (Vespertilionidae).

It is important to mention that ectoparasites were seen on the following bats species, but they were not collected: Artibeus cinereus (Gervais, 1856), A. lituratus, Chrotopterus auritus (Peters, 1856), Platyrrhinus helleri (Peters, 1866).

Including our results, the number of species of bat flies in Goiás state increased to four Basilia and 17 for Streblidae species. Although our work is the first inventory carried out in this state, the number of recorded species is surpassed only by the Distrito Federal, and Paraná, São Paulo, Pará, Santa Catarina, and Minas Gerais states (Table 1), but those areas have a higher number of inventories of bat flies (Graciolli et al. 2008). New inventories are necessary to help understanding the host-parasite relationship in the Cerrado biome, and the number of records of bat flies will probably increase in the state.

Acknowledgements. GG thanks the Conselho Nacional de Pesquisas e Desenvolvimento Científico e Tecnológico (CNPq) for grant (Proc. \#304459/2008-9).

\section{REFERENCES}

Dias, P. A.; C. L. C. dos Santos; F. S. Rodrigues; L. C. Rosa; K. S. Lobato \& J. M. M. Rebelo. 2009. Espécies de moscas ectoparasitas (Diptera, Hippoboscoidea) de morcegos (Mammalia, Chiroptera) no estado do Maranhão. Revista Brasileira de Entomologia 53: 128-133.

FUNATURA. 1999. Plano de manejo Reserva Natural Pousada das Araras. Brasília, FUNATURA, 215 p.

Graciolli, G.; A. G. Autino \& G. L. Claps. 2007. Catalogue of American Nycteribiidae (Diptera, Hippoboscoidea). Revista Brasileira de Entomologia 51: 142-159.

Graciolli, G.; A. A. Azevedo; M. Árzua; D. Battesti \& P. M. Linardi. 2008. Artrópodos Ectoparasitos de Morcegos no Brasil, p. 123-138. In: S. M. Pacheco; R. V. Marques \& C. E. L. Esbérard. (Org.). Morcegos no Brasil: biologia, sistemática, ecologia e conservação. $1^{\text {a }}$ ed., Porto Alegre, Armazém Digital, 504 p.

Graciolli, G.; N. C. Cáceres \& M. R. Bornschein. 2006. Novos registros de moscas ectoparasitas (Diptera, Streblidae e Nycteribiidae) de morcegos (Mammalia, Chiroptera) em áreas de transição cerradofloresta estacional no Mato Grosso do Sul, Brasil. Biota Neotropica 6:http://www.biotaneotropica.org.br/v6n2/pt/abstract? shortcommunication+bn03206022006 (accessed 13 October 2009).

Komeno, C. A. \& A. X. Linhares. 1999. Batflies parasitic on some phyllostomid bats in Southeastern Brazil: parasitism rates and hostparasite relationships. Memórias do Instituto Oswaldo Cruz 94: $151-156$.

Köppen, W. 1948. Climatologia. México, Fundo de Cultura Econômica, 478 p.

Lima, J. E. F. W. \& E. M. Silva. 2005. Estimativa da produção hídrica superficial do Cerrado brasileiro, p. 61-72. In: Scariot A.; J. C. SousaSilva \& J. M. Felfili (Orgs.). Cerrado: Ecologia, Biodiversidade e Conservação. Brasília, Ministério do Meio Ambiente, 439 p. 
Pessôa, S. B. \& L. R. Guimarães. 1936. Notas sobre Streblidae (Diptera), com a descrição de um novo genero e duas novas especies. Anais da Faculdade de Medicina da Universidade de São Paulo 12: 255-267.

Rios, G. F. P.; R. J. Sá-Neto \& G. Graciolli. 2008. Fauna de dípteros parasitas de morcegos em uma área de Caatinga do nordeste do Brasil. Chiroptera Neotropical 14: 339-345.

Wenzel, R. L. 1976. The streblid batflies of Venezuela (Diptera: Streblidae). Brigham Young of University Sciences Bulletin, Biological Series 20: $1-177$.
Wenzel, R. L.; V. J. Tipton \& A. Kiewlicz. 1966. The streblid batflies of Panama (Diptera: Calyptera: Streblidae), p. 405-675. In: R. L. Wenzel \& V. J. Tipton (eds.). Ectoparasites of Panama. Chicago, Field Museum of Natural History, xii+861 p.

Zortéa, M. \& C. J. R. Alho. 2008. Bat diversity of a Cerrado habitat in Central Brazil. Biodiversity Conservation 17: 791-805.

Received 14/08/2009; accepted 08/07/2010

Editor: Silvio Shigueo Nihei 